\section{Rainfall trend analysis in the Lower Gangetic Plain: a study on selected rainfall stations of Maldah district, West Bengal, India}

\author{
Suman Kumar Kundu* \\ Department of Geography, University of Kalyani, Nadia 741 235, India
}

Changes in rainfall pattern are of significance in terms of water resource management, hydrological modelling, environmental hazard management and agricultural planning. In the present study $I$ assess the annual and seasonal rainfall trend, including concentration in eight rainfall stations in Maldah district, located in the lower Gangetic plain of West Bengal, India during 1985-2015. Besides the Mann-Kendall test and Theil-Sen's estimator for assessing the trend of rainfall, precipitation concentration index (PCI) has been used to examine intra-annual rainfall variability. The study reveals decreasing trend of annual and monsoon rainfall in seven rainfall stations. Among them, significant trend is found in five and four rainfall stations respectively. This is followed by pre-monsoon and post-monsoon rainfall characterized with decreasing trend in five and eight rainfall stations respectively. The results of PCI show fluctuation of rainfall distribution in the district from moderate to strong irregular during the study period. However, decreasing trend of annual PCI values in the seven rainfall stations, with significant value in one of them, implies a tendency towards moderate rainfall distribution in the respective stations. Nevertheless, ChanchalI rainfall station solely showed increasing annual PCI value and thereby an affinity towards strong irregular distribution of rainfall. Despite decrease in annual and seasonal rainfall, increase of pre-June (May) and post-September (October) rainfall prolonged the rainy season, which is responsible for drainage congestion as well as seasonal inundation in low-lying areas of the district.

Keywords: Precipitation concentration index, rainfall stations, trend analysis, water resource management.

ACCORDING to India Meteorological Department (IMD), there are four meteorological seasons over India, viz. winter season: January and February; pre-monsoon season: March to May; southwest monsoon season: June to September and post-monsoon season: October to December. The Indian SW monsoon season provides $75-90 \%$ of the total annual rainwater in most parts of the country ${ }^{1}$. It is essential 'for the availability of freshwater for drinking and irrigation, agricultural production, power generation, water resources management and the overall economy of the country' ${ }^{2}$. Several studies have dealt with the intra-

\footnotetext{
*e-mail: s.k.kundu23@gmail.com
}

seasonal and interannual variability of Indian summer monsoon (ISM) rainfall at diverse scales, including its underlying cause and prediction probability ${ }^{2-4}$. Changes in rainfall pattern over a region have an impact on surface run-off, soil erosion, moisture content in the soil, groundwater storage, and severity of droughts and floods ${ }^{2}$. Therefore, analysis of seasonal and annual rainfall variability has gained importance in terms of 'water management policies', 'planning sustainable agriculture practices' and other environmental issues ${ }^{5}$.

The Lower Gangetic Plain being enriched with fertile alluvial soil coupled with favourable climatic conditions for growing a large number of food crops, is an important agro-climatic zone in India. Rainfed agriculture practised in this vast tract of the country is entirely dependent upon monsoon rainfall. Therefore, the vagaries of the SW monsoon directly influence the production of principal crops and the fate of people associated with it. A comprehensive study about water resource management in this region would aid in sustainable agriculture practice. For the purpose of water resource planning in a small watershed or in a river basin for sustaining irrigation or agricultural practice, rainfall information at the local scale is much more important than over a large scale ${ }^{6}$. However, there is no comprehensive study dealing with the spatio-temporal variability of rainfall and its longterm trends at micro-level in the lower Gangetic Plain. Maldah district situated in the lower Gangetic Plain of West Bengal, experiences marked inter-regional differences in terms of topography, soil, drainage pattern and climatic characteristics. Agriculture is the mainstay of the district economy; $52.08 \%$ of the total workforce is directly engaged in agriculture ${ }^{7}$. With respect to the physical environment influencing agricultural activities in the district, occurrence of rainfall largely determines the farmer's crop choice and cropping pattern. Therefore, the main objectives of this study are: (i) to examine the variability of annual and seasonal rainfall trends in Maldah district during 1985-2015; (ii) to evaluate the trend of precipitation concentration and contribution of monthly rainfall in changing precipitation concentration in the district during the same period.

The Lower Ganga Plain extending from south and east of the Rajmahal-Garo gap to the modern shorelines forms an integral part of the Ganga dispersal system ${ }^{8}$. The Maldah district is an important part of this system. The district is located between $24^{\circ} 40^{\prime} 20^{\prime \prime}-25^{\circ} 32^{\prime} 8^{\prime \prime} \mathrm{N}$ lat. and $87^{\circ} 45^{\prime} 50^{\prime \prime}-88^{\circ} 28^{\prime} 10^{\prime \prime} \mathrm{E}$ long., with an area of about 3733 sq. km. River Ganges flows through the western extremities of the district. On the basis of physiography, drainage pattern and soil characteristics, the Maldah district can be sub-divided into three broad ecological sub-regions, viz. Tal, Barind and Diara'. Tal region situated to the west of River Mahananda covers the CD Blocks (Community Development Blocks) of Harischandrapur-I, Harischandrapur-II, Chanchal-I, Chanchal-II, 

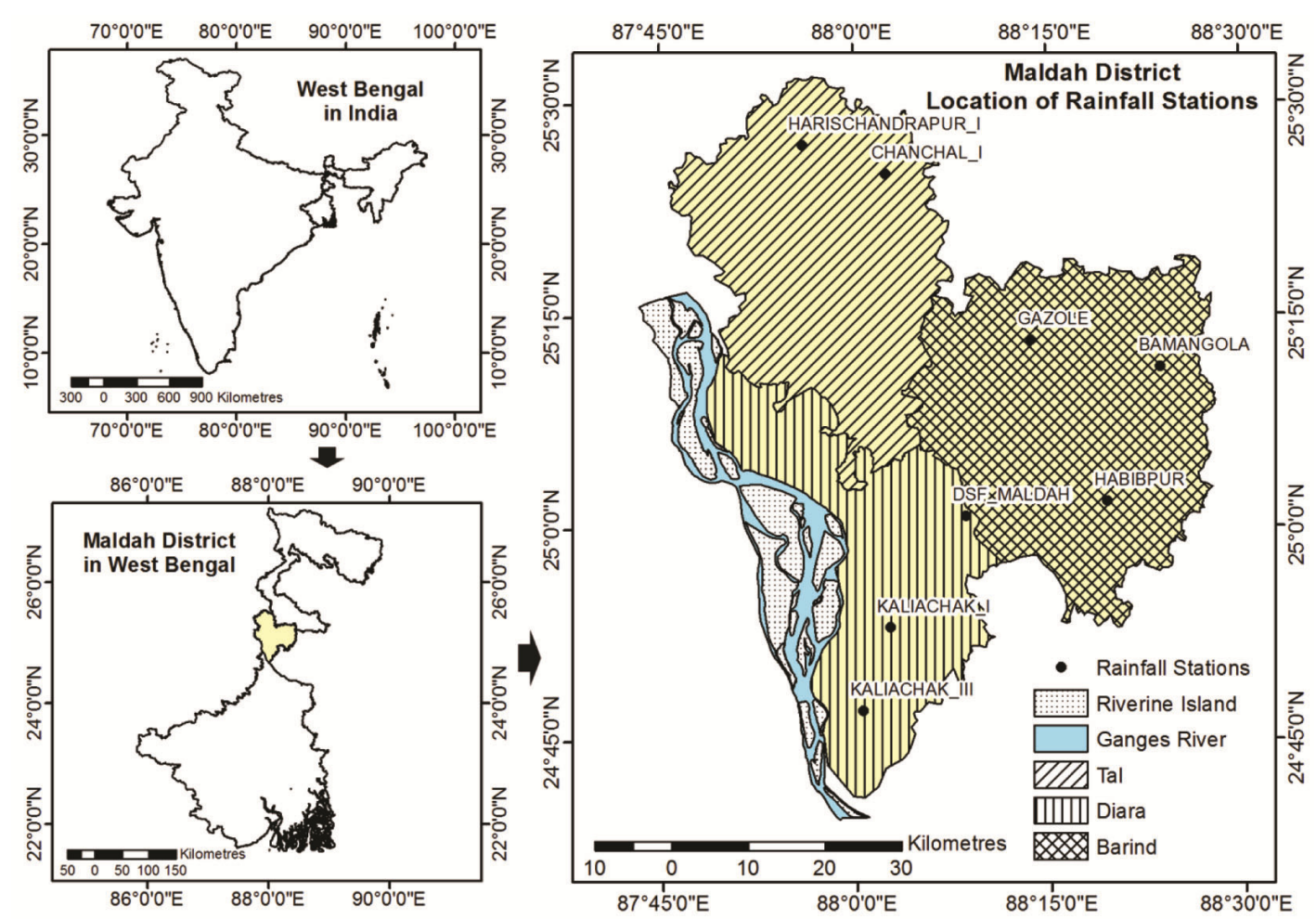

Figure 1. Location of rainfall stations in Maldah district, West Bengal, India.

Ratua-I and Ratua-II. The Barind tract is situated to the east of the River Mahananda including the CD Blocks of Gazole, Bamangola, Habibpur and Maldah (Old). Diara is the transitional zone between the Barind upland and the marshy Tal tract. It covers the CD Blocks of Manikchak, English Bazar, Kaliachak-I, Kaliachak-II and KaliachakIII. Monthly rainfall data of Maldah district were collected from the Office of Agricultural Meteorologist, Deputy Director of Agriculture (Administration), Maldah district, Government of West Bengal, for the period 1985-2015. I have used monthly rainfall data of eight rainfall stations situated mainly at the eastern-most part in the district, viz. Chanchal-I, Harischandrapur-I (Tal); Gazole, Bamangola, Habibpur (Barind); Kaliachak-I, Kaliachak-III and DSF (District Seed Farm) Maldah (Diara) for the study (Figure 1). Old Maldah station was excluded due to unavailability of rainfall data for the entire study period. There are four principal seasons in Maldah district, (i) winter - January and February; (ii) pre-monsoon - March to May; (iii) monsoon - June to September and (iv) post-monsoon - October to December. Rainfall usually increases from the southwest to the northwest in the district. The average annual rainfall in the district was $1527.6 \mathrm{~mm}$ during the study period (1985-2015) (Figure 1).

Precipitation concentration index (PCI) has been used as a statistical descriptor of precipitation variability. Following Oliver ${ }^{10}$, the annual PCI values have been calculated as

$$
\mathrm{PCI}_{\text {Annual }}=\frac{\sum_{i=1}^{12} P_{i}^{2}}{\left(\sum_{i=1}^{12} P_{i}\right)^{2}} \times 100
$$

where $P_{i}$ is the amount of monthly precipitation in the $i$ th month. Based on eq. (1), the minimum theoretical value of PCI is 8.3 , representing complete uniformity in precipitation concentration (i.e. the same amount of precipitation occurred during each month). A PCI value of 16.7 indicates that the whole precipitation has been concentrated within half of the time period, while a PCI value of 25 also indicates that precipitation occurred in one-third of the time period (i.e. the total annual precipitation occurred in four months). According to this classification scheme, Oliver ${ }^{10}$ suggests that a PCI of less than $10 \mathrm{im}-$ plies uniform precipitation distribution (low precipitation concentration); a value from 11 to 15 denotes a moderate precipitation concentration, while a value from 16 to 20 denotes an irregular precipitation distribution. An index above 20 represents strong irregularity in precipitation distribution (high precipitation concentration), with increasing values indicating increasing monthly precipitation concentration ${ }^{11}$.

To detect the monthly, seasonal and annual rainfall trend, including annual PCI, the non-parametric MannKendall trend test was used in this study ${ }^{12,13}$. One of the 
advantages of this test is that it 'identifies the presence of a trend without making an assumption about the properties of the distribution, ${ }^{14}$. The Mann-Kendall test is appropriate when the data values $x_{i}$ of a time series can be assumed to follow the model ${ }^{15}$.

$$
x_{i}=f\left(t_{i}\right)+\varepsilon_{i},
$$

where $f(t)$ is a continuous monotonic increasing or decreasing function of time, and the residuals $\varepsilon_{\mathrm{i}}$ can be assumed belonging to the same distribution with zero mean and constant variance in time.

In this trend test, the null hypothesis $H_{0}$, indicates that there is no trend in population from which the data are drawn, against the alternative hypothesis $H_{1}$, where there is increasing or decreasing monotonic trend. The test statistic $S$ is applied for time series with less than 10 data points, and normal approximation ( $Z$ statistics) is used for time series with 10 or more data points.

The Mann-Kendall test statistic $S$ is calculated using the formula

$$
S=\sum_{i=1}^{n-1} \sum_{j=i+1}^{n} \operatorname{sgn}\left(x_{j}-x_{i}\right),
$$

where $x_{j}$ are the sequential data values, $n$ the length of the dataset and

$$
\operatorname{sgn}(t)= \begin{cases}1, & \text { for } t>0 \\ 0, & \text { for } t=0 \\ -1, & \text { for } t<0\end{cases}
$$

A positive value of $S$ describes a rising trend in the series, while a negative value of $S$ indicates a falling trend. In the Mann-Kendall trend test when $n \geq 8$, the test statistic $S$ is approximately normally distributed with mean and variance as

$$
E(S)=0
$$

$$
\operatorname{Var}(S)=\frac{n(n-1)(2 n+5)-\sum_{i=1}^{m} t_{i}\left(t_{i}-1\right)\left(2 t_{i}+5\right)}{18},
$$

where $m$ is the number of tied groups and $t_{i}$ is the size of the $i$ th tie group. The standardized test statistics $Z$ is computed as

$$
Z_{\mathrm{MK}}=\left\{\begin{array}{cl}
\frac{S-1}{\sqrt{\operatorname{Var}(S)},} & \text { for } S>0 \\
0, & \text { for } S=0 . \\
\frac{S+1}{\sqrt{\operatorname{Var}(S)},}, \text { for } S<0
\end{array}\right.
$$

Positive values of $Z$ indicate upward trend, whereas negative values depict downward trend. For testing either an upward or downward monotone trend (a two-tailed test) at $\alpha(0.05)$ significance level, the null hypothesis $\left(H_{0}\right)$ is rejected if the absolute value of $Z$ is greater than $Z_{1-\alpha / 2}$, where $Z_{1-\alpha / 2}$ is obtained from the standard normal cumulative distribution tables ${ }^{15}$.

The magnitude of trends in the rainfall and PCI time series was estimated using the nonparametric Theil-Sen's estimator $^{16,17}$. The procedure is as follows

$$
\beta=\operatorname{median}\left(\frac{X_{i}-X_{j}}{i-j}\right), \forall j<i .
$$

In eq. (8), $1<j<i<n$. 'The estimator $\beta$ is the median over all combinations of record pairs for the whole dataset and is thereby resistant to the effect of extreme values in the observations, ${ }^{18}$.

The main assumption of the Mann-Kendall trend test is that the data are independent and randomly ordered, i.e. there is no serial correlation in the time-series data. However, hydrological time series exhibits significant autocorrelation coefficient ${ }^{19}$. To eliminate the problem of serial correlation in the Mann-Kendall test, Von Storch ${ }^{20}$ has proposed the 'pre-whitened' method. The effects of serial correlation in Sen's slope estimator can also be eliminated using this method ${ }^{21}$. However, the prewhitening approach is inappropriate for series having negative serial correlation ${ }^{22}$. Yue et al. ${ }^{23}$ have developed the 'trend-free pre-whitening' (TFPW) approach as a modified form of the pre-whitening method to the series in which there was either positive or negative serial correlation. The computed Durbin-Watson statistics ${ }^{24-26}$ for monthly, annual, seasonal rainfall time series and annual PCI time series have reported the presence of serial correlation. The table values of Durbin-Watson statistics for 31 observations and two regressors (including the constant term) at lower (dL) and upper (dU) 5\% significance level are 1.363 and 1.496 respectively, which are much greater than the computed value of Durbin-Watson statistics (Supplementary Material 2). Therefore, the TFPW method has been applied to remove serial correlation from the respective rainfall and PCI time series in the selected rainfall stations of Maldah district. The MannKendall test has been performed on the TFPW series to obtain trend of rainfall and PCI, i.e. either increasing or decreasing at $95 \%$ confidence level.

The spatial distribution of annual and seasonal rainfall trend during 1958-2015 has been presented by plotting the results of Mann-Kendall test and Theil-Sen's slope on the outline map of Maldah district using symbolic and numeric expressions respectively (Figure 2). Maldah district is flanked by monsoon rainfall providing $77 \%$ of total annual rainfall to the district. Agriculture of the district is rainfed and the production of kharif crops is 

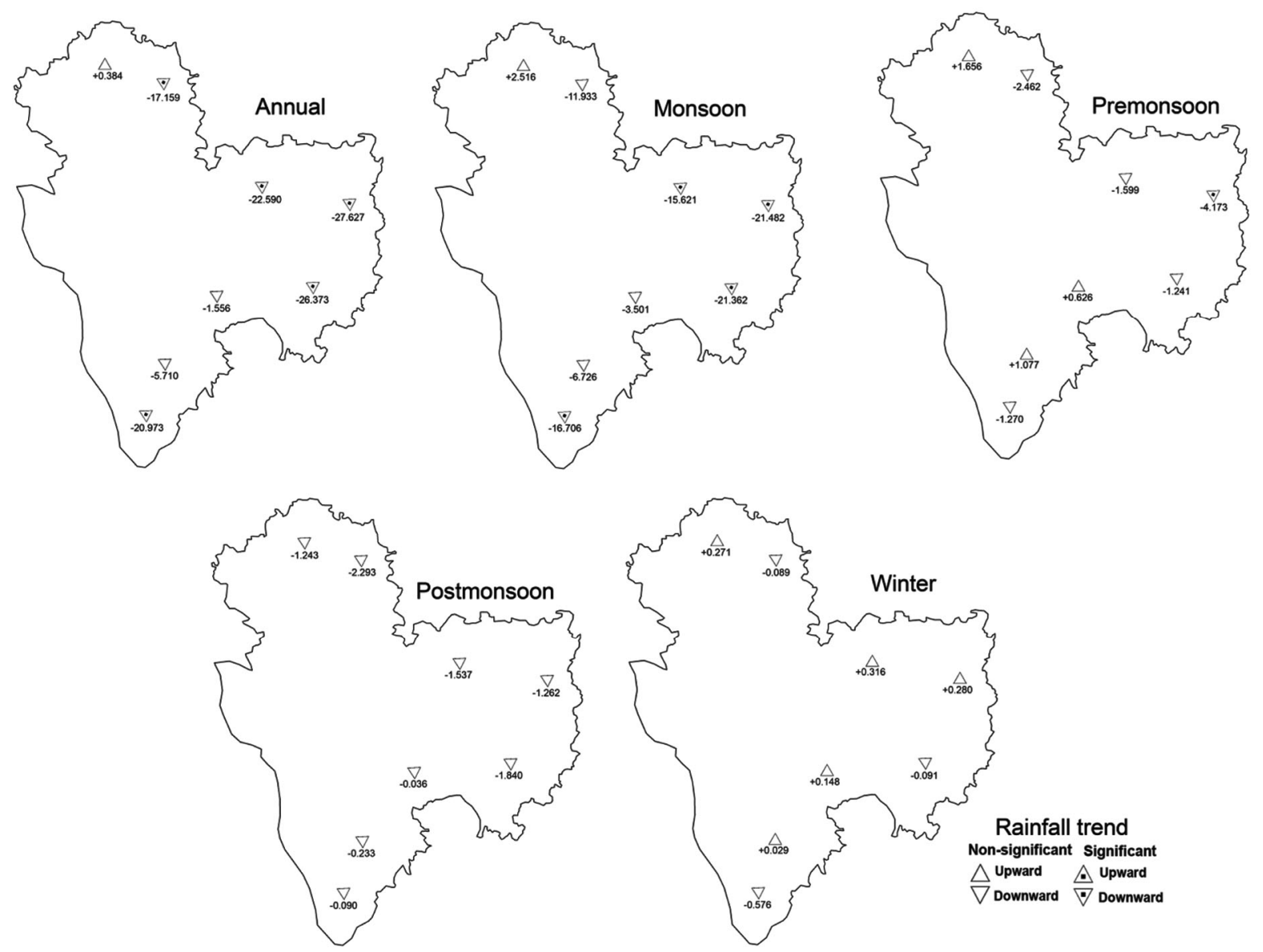

Figure 2. Annual and seasonal rainfall trend and Theil-Sen's slope (mm/year) in Maldah district (1985-2015).

entirely dependent upon monsoon rainfall during June to September. Timely and adequate rainfall in the monsoon months has an impact on crop phenology, which determines the production of agricultural crops. However, monsoon rainfall in the region recorded decreasing trend in seven rainfall stations, with statistically significant trend (at 95\% confidence level) among four of them, viz. Gazole, Bamangola, Habibpur and Kaliachak-III (Figure 2). Das et $a$. $^{2}$ while studying spatio-temporal trend of precipitation and rainy days during ISM season for the period of 1971-2005 using Mann-Kendall and Sen's method, found similar results of decreasing trend of rainfall in the monsoon months over Gangetic West Bengal. Monsoon rainfall shrinking at an alarming rate in the Barind region ranges between $-15.621 \mathrm{~mm} /$ year in Gazole and $-21.482 \mathrm{~mm} /$ year in Habibpur station. The decreasing trend of ISM rainfall (ISMR) at a large spatial scale is attributed to the weakening of easterly jet stream and the Southern Oscillation followed by 'more warming of equatorial Indian Ocean than northern latitudes of the tropics, weakening of the meridional SST gradient from the equatorial region to the south Asian coast during summer, and decreasing tendency in the occurrence of cyclonic systems over north Indian Ocean,27. However, the ISM system responds in a complex way to 'global climatic forcing', where homogeneous changes throughout the Indian monsoon region are not be expected to occur $^{28}$. Therefore local factor in the form of land use and land cover changes by means of deforestation that 'results in weakening of the ISMR because of the decrease in evapotranspiration and subsequent decrease in the recycled component of precipitation ${ }^{29}$. The large-scale deforestation for expansion of agricultural land in the vast Barind tract of Maldah district is one of the major factors causing decreasing monsoon rainfall trend in the district.

In addition, pre-monsoon and post-monsoon rainfall contributing $12 \%$ and $9.5 \%$ of total annual rainfall respectively, in the district, showed a decreasing trend in five and eight rainfall stations respectively. Winter rainfall holding negligible share $(1.5 \%)$ in the total annual rainfall portrays insignificant decreasing trend in three rainfall stations. This decreasing seasonal rainfall trend can be attributed to the decrease in total annual rainfall in the entire district. Seven rainfall stations of the district exhibit decreasing trend of annual rainfall with statistically significant trend in Chanchal-I, Gazole, Bamangola, Habibpur and Kaliachak-III rainfall stations. There is 

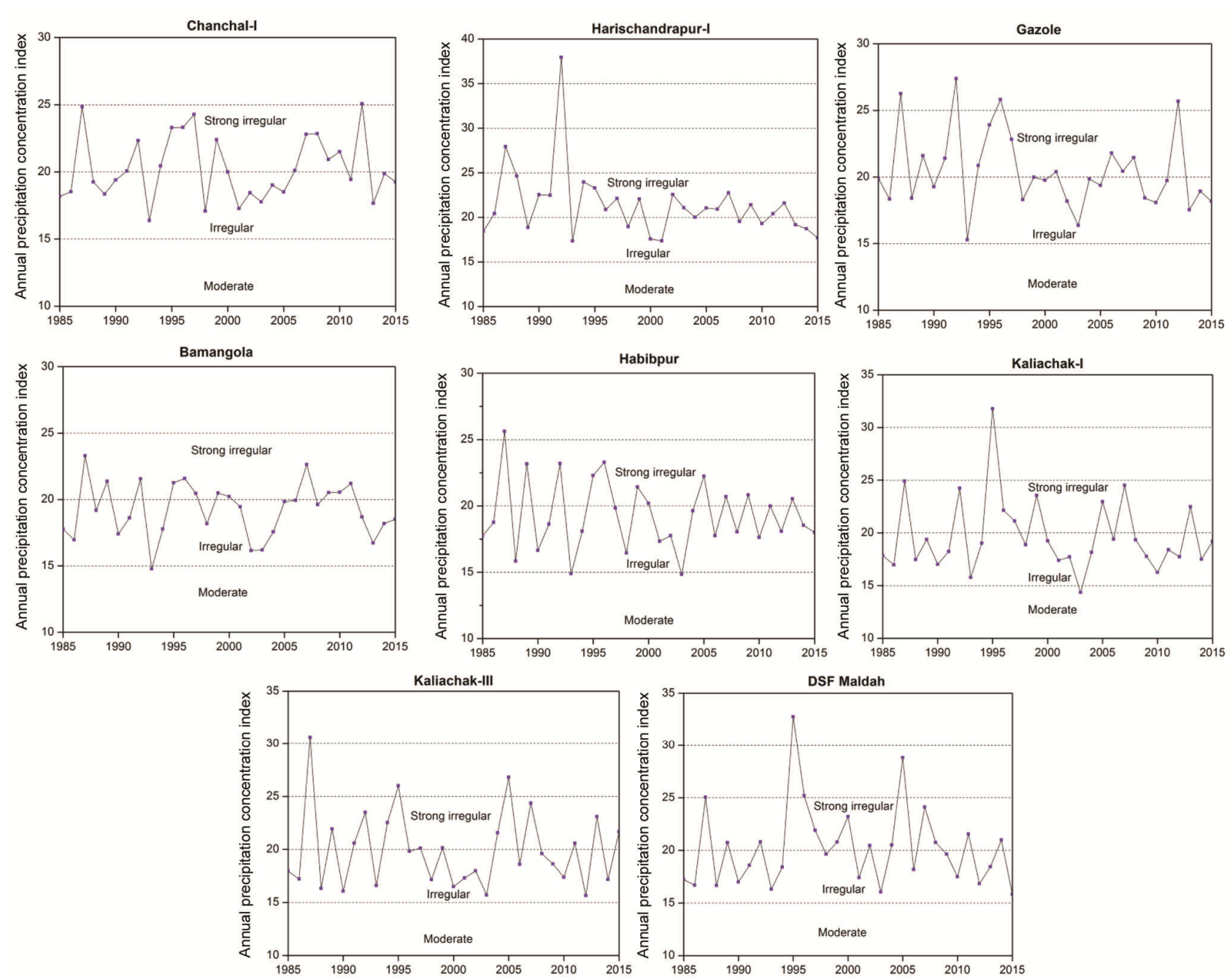

Figure 3. Annual precipitation concentration index of rainfall stations in Maldah district (1985-2015).

Table 1. Variability of annual precipitation concentration index values of rainfall stations in Maldah district, West Bengal, India (1985-2015)

\begin{tabular}{lccc}
\hline Rainfall station & Mean & $\begin{array}{c}\text { Standard } \\
\text { deviation }\end{array}$ & $\begin{array}{c}\text { Coefficient of } \\
\text { variation }\end{array}$ \\
\hline Chanchal-I & 20.27 & 2.40 & 11.83 \\
Harischandrapur-I & 21.39 & 3.87 & 18.11 \\
Gazole & 20.44 & 2.90 & 14.21 \\
Bamangola & 19.25 & 2.03 & 10.56 \\
Habibpur & 19.29 & 2.60 & 13.50 \\
Kaliachak-I & 19.70 & 3.50 & 17.75 \\
Kaliachak-III & 19.97 & 3.62 & 18.12 \\
DSF Maldah & 20.26 & 3.86 & 19.05 \\
\hline
\end{tabular}

huge decrease in magnitude of annual rainfall found in three rainfall stations of Barind region, viz. Bamangola (-27.627 mm/year), Habibpur (-26.373 mm/year) and Gazole $(22.590 \mathrm{~mm} /$ year $)$, followed by Kaliachak-III station of Diara region (-20.973 mm/year) and Chanchal-I station of Tal region $(-17.159 \mathrm{~mm} /$ year $)$. The Harischandrapur-I rainfall station of Tal region located at the extreme northern corner of the district solely experiences
Table 2. Mann-Kendall $Z$ statistics and Theil-Sen's estimator of annual PCI time series in Maldah district (1985-2015)

\begin{tabular}{lcc}
\hline Rainfall station & $\begin{array}{c}\text { Mann-Kendall } \\
Z \text { statistics }\end{array}$ & $\begin{array}{c}\text { Theil-Sen's } \\
\text { estimator }\end{array}$ \\
\hline Chanchal-I & 0.36 & 0.018 \\
Harischandrapur-I & $-\mathbf{2 . 6 8}$ & -0.136 \\
Gazole & -1.39 & -0.073 \\
Bamangola & -0.50 & -0.020 \\
Habibpur & -0.64 & -0.044 \\
Kaliachak-I & -0.29 & -0.019 \\
Kaliachak-III & -0.46 & -0.027 \\
DSF Maldah & -0.11 & -0.007 \\
\hline Note: Value in boldface is significant at $95 \%$ confidence level.
\end{tabular}

insignificant increasing trend in annual as well as seasonal rainfall (except post-monsoon season). However, the magnitude of trend of annual rainfall in HarischandrapurI is low $(+0.384 \mathrm{~mm} /$ year $)$ in the regional perspective (Figure 2).

PCI has been used to assess intra-annual rainfall variability in the selected rainfall stations of Maldah district. PCI is the statistical measurement of degree of variability 
RESEARCH COMMUNICATIONS

Table 3. Mann-Kendall $Z$ statistics of monthly rainfall time series in Maldah district (1985-2015)

\begin{tabular}{|c|c|c|c|c|c|c|c|c|}
\hline Month & Chanchal-I & Harischandrapur-I & Gazole & Bamangola & Habibpur & Kaliachak-I & Kaliachak-III & DSF Maldah \\
\hline January & -0.93 & -0.27 & 0.02 & 0.00 & 0.09 & 0.71 & -0.20 & 0.23 \\
\hline February & 0.00 & 1.21 & 0.95 & 0.70 & -1.11 & -0.37 & -1.50 & -0.64 \\
\hline March & 0.09 & 0.45 & 0.89 & -0.34 & -0.23 & -0.93 & -0.73 & -0.50 \\
\hline April & -0.46 & 0.54 & -0.73 & -0.64 & -0.86 & 0.89 & -0.68 & 0.21 \\
\hline May & -1.14 & 0.29 & -0.75 & -2.57 & -0.79 & 0.61 & 0.11 & 0.79 \\
\hline June & -0.18 & 1.14 & 0.21 & 0.07 & 0.54 & -0.04 & -0.54 & 0.79 \\
\hline July & -1.21 & -0.25 & -2.46 & -3.10 & -2.28 & -0.14 & -1.03 & -0.57 \\
\hline August & -0.18 & 1.18 & -1.25 & -1.86 & -1.11 & -0.32 & -1.46 & -0.07 \\
\hline September & -2.11 & -0.75 & -1.11 & -2.11 & -2.85 & -1.07 & -1.96 & -2.32 \\
\hline October & -0.86 & -0.04 & -0.25 & 0.04 & -0.21 & 0.29 & 0.21 & 0.57 \\
\hline November & -2.32 & -2.53 & -2.09 & -1.53 & -0.16 & -0.53 & -1.68 & -1.28 \\
\hline December & -3.81 & -2.70 & -3.31 & -3.75 & -2.62 & -2.49 & -1.56 & -3.39 \\
\hline
\end{tabular}

Note: Values in boldface are significant at $95 \%$ confidence level.

of precipitation distribution over 12 months $^{14}$. Annual PCI in the selected eight rainfall stations of Maldah district showed large variation throughout the study period, 1985-2015 (Table 1 and Figure 3). Following Oliver ${ }^{10}$, Bamangola, Habibpur and Kaliachak-I rainfall stations showed fluctuation in the distribution in the rainfall in a year from moderate to strong irregular during the study period. Meanwhile, rest five stations of the district experienced variation between irregular to strong irregular distribution of rainfall over a year. However, the MannKendall trend test and Theil-Sen's estimator outlined an interesting insight of annual PCI trend in the study area. Except Chanchal-I, the entire selected rainfall stations of the district recorded decreasing trend of annual PCI values during 1985-2015, with statistically significant trend (at 95\% confidence level) in Harischandrapur-I station. The magnitude of annual PCI trend in the respective rainfall stations varied between $-0.007 /$ year in DSF Maldah and $-0.136 /$ year in Harischandrapur-I station. This indicates an affinity of moderate distribution of rainfall over the year in the entire district. Chanchal-I rainfall station of Tal region solely exhibited statistically insignificant increasing trend of annual PCI throughout the study period having magnitude of trend +0.018 /year (Table 2 ). This implies a tendency towards strong irregularity of rainfall distribution over the year and high concentration during few months (Table 2).

The monthly rainfall trends and their magnitude as represented by Mann-Kendall $Z$ statistics and TheilSen's slope (mm/year) respectively, portray relative contribution of monthly rainfall over changing distributional pattern of 12 months' rainfall in the selected stations of Maldah district (Tables 3 and 4). No significant increasing trend was observed in monthly rainfall time series in the selected rainfall stations of the district. However, the largest insignificant increasing trend of rainfall in the non-monsoon months $(79 \%)$ in the district justifies the tendency towards spread of the rainfall event beyond monsoon months. Harischandrapur-I rainfall station experiencing a tendency towards moderate distribution of rainfall event throughout the year as evident from signifi- cant decreasing trend of annual PCI value, recorded the highest insignificant increasing trend in non-monsoon months followed by insignificant increasing trend in the monsoon months (June and August). Non-monsoon month of December experienced significant decreasing trend in the entire district, except Kaliachak-III rainfall station, with magnitude ranging between $-0.008 \mathrm{~mm} /$ year in Habibpur and $-0.168 \mathrm{~mm} /$ year in Gazole station. This is followed by the month of November where Chanchal-I, Harischandrapur-I and Gazole rainfall stations witnessed significant decreasing trend of rainfall having TheilSen's slope value ranges between -0.099 and $-0.316 \mathrm{~mm} /$ year. The increase (decrease) in the amount of pre-June and post-September precipitation signifies an effective increase (decrease) in rainy season ${ }^{27}$. Despite decrease in monsoon rainfall, increase of pre-June (May) and post-September (October) rainfall in Kaliachak-I, Kaliachak-III and DSF Maldah rainfall stations would result in prolonged rainy season. Therefore, heavy downpour during the rainy season adds to excessive run-off from upper catchment area by the major rivers during monsoon to post-monsoon seasons, causing drainage congestion and inundation in low-lying areas adjacent to the respective stations of the district. Among monsoon months, July and September experienced decreasing trend in the entire district with significant $Z$ value in three (Gazole, Bamangola and Habibpur) and five (Chanchal-I, Bamangola, Habibpur, Kaliachak-III and DSF Maldah) rainfall stations respectively, having magnitude of trend varying between -4.387 and $-10.740 \mathrm{~mm} /$ year. However, the monsoon month of June witnessed insignificant increasing trend in five rainfall stations of the district, viz. HarischandrapurI, Gazole, Bamangola, Habibpur and DSF Maldah with magnitude ranging between +0.311 and $+4.105 \mathrm{~mm} /$ year. It was followed by Harischandrapur-I rainfall station solely in August ( $+4.478 \mathrm{~mm} /$ year) (Tables 2 and 3).

This study reveals severe intra-regional disparity regarding long-term trends of rainfall and its 12 months' distribution during the period 1985-2015 in eight rainfall stations situated in Maldah district of the Lower Gangetic Plain. Monsoon as well as annual rainfall witnessed a 


\section{RESEARCH COMMUNICATIONS}

Table 4. Theil-Sen's slope (mm/year) of monthly rainfall time series in Maldah district (1985-2015)

\begin{tabular}{lccccrrrr}
\hline Month & Chanchal-I & Harischandrapur-I & Gazole & Bamangola & Habibpur & Kaliachak-I & Kaliachak-III & DSF Maldah \\
\hline January & -0.130 & 0.000 & 0.000 & 0.000 & 0.000 & 0.000 & 0.000 \\
February & -0.009 & 0.240 & 0.243 & 0.151 & -0.346 & -0.101 & -0.486 & -0.147 \\
March & 0.009 & 0.033 & 0.045 & 0.000 & -0.077 & -0.314 & -0.300 & -0.180 \\
April & -0.364 & 0.393 & -0.587 & -0.574 & -0.656 & 0.438 & -0.429 & 0.200 \\
May & -1.835 & 0.215 & -1.310 & -3.791 & -0.743 & 1.128 & 0.126 & 1.221 \\
June & -0.588 & 4.105 & 1.051 & 0.311 & 1.231 & -0.317 & -1.562 & 2.653 \\
July & -4.662 & -0.992 & -9.119 & -10.740 & -7.413 & -0.330 & -3.871 & -2.097 \\
August & -0.738 & 4.478 & -3.628 & -5.079 & -2.454 & -0.472 & -5.348 \\
September & -6.047 & -2.827 & -3.993 & -6.647 & -8.384 & -3.400 & -5.633 & -0.142 \\
October & -1.117 & -0.070 & -0.324 & 0.178 & -0.221 & 0.939 & 0.588 & -4.387 \\
November & -0.117 & 0.000 & -0.099 & -0.137 & 0.000 & 0.000 & -0.316 & -0.198 \\
December & -0.080 & -0.067 & -0.168 & -0.028 & -0.008 & -0.014 & 0.000 & -0.071 \\
\hline
\end{tabular}

decreasing trend in seven rainfall stations of the district, with comparatively higher magnitude of trend in Bamangola and Habibpur rainfall stations in the Barind region. The district is characterized by gradual irregular distribution of annual precipitation from previous strong irregularity, as reflected by a decreasing trend in annual PCI values in seven rainfall stations. Chanchal-I rainfall station solely experienced an increasing trend in annual PCI and thereby a tendency towards strong irregularity in distribution of 12 months' rainfall distribution. Largest number of increasing trend in non-monsoon months (79\%) implies spread of rainfall event beyond the monsoon months in Maldah district. Increase in rainfall during pre- and post-monsoon months would prolong the rainy season and increase the probability of occurrence of seasonal inundation in low-lying areas of the district. Seasonal inundation hampers multiple cropping practices in large tracts of the district, where farmers are compelled to indulge in double-cropping throughout the year. The present study would aid in the management of potential rainwater harvesting sites where regional pattern of rainfall can be blended with the secondary information of groundwater resources for providing irrigation water to sustain agriculture practice in lean monsoon months as well as dry season in Maldah district.

1. Parthasarathy, B., Interannual and long-term variability of Indian summer monsoon rainfall. Proc. Indian Acad. Sci-Earth Planet. Sci., 1984, 93(4), 371-385.

2. Das, P. K., Chakraborty, A. and Seshasai M. V. R., Spatial analysis of temporal trend of rainfall and rainy days during the Indian summer monsoon season using daily gridded $(0.5 \times 0.5)$ rainfall data for the period of 1971-2005. Meteorol. Appl., 2014, 21(3), 481-493.

3. May, W., Simulation of the variability and extremes of daily rainfall during the Indian summer monsoon for present and future times in a global time-slice experiment. Climate Dyn., 2004, 22(23), 183-204.

4. Pattanaik, D. R. and Rajeevan, M., Variability of extreme rainfall events over India during southwest monsoon season. Meteorol. Appl., 2010, 17(1), 88-104.

5. Huang, J., Sun, S., Xue, Y. and Zhang, J., Changing characteristics of precipitation during 1960-2012 in Inner Mongolia, northern China. Meteorol. Atmos. Phys., 2015, 127(3), 257-271.
6. Ghosh, S., Luniya, V. and Gupta, A., Trend analysis of Indian summer monsoon rainfall at different spatial scales. Atmos. Sci. Lett., 2009, 10, 285-290.

7. Census of India, District Census Handbook: Maldah, Village and Town wise Primary Census Abstract (PCA), Series 20, Part XII-B, Directorate of Census Operations, Government of West Bengal, 2011.

8. Tandon, S. K., Sinha, R., Gibling, M. R., Dasgupta, A. S. and Ghazanfari, P., Late Quaternary evolution of the Ganga Plains: myths and misconceptions, recent developments and future directions. Golden Jubilee Mem. Geol. Soc. India, 2008, 66, 259-299.

9. Sengupta, J. C., West Bengal District Gazetteers: Malda, Director, District Gazetteers, Government of West Bengal Press, Calcutta, 1969.

10. Oliver, J. E., Monthly precipitation distribution: a comparative index. Prof. Geogr., 1980, 32(3), 300-309.

11. Luis, M. D., González-Hidalgo, J. C., Brunetti, M. and Longares, L. A., Precipitation concentration changes in Spain 1946-2005. Nat. Hazards Earth Syst. Sci., 2011, 11(5), 1259-1265.

12. Mann, H. B., Nonparametric tests against trend. Econometrica: J. Econ. Soc., 1945, 13, 245-259.

13. Kendall, M., Rank Correlation Methods, Charles Griffin. San Francisco, CA, USA, 4th edn, 1975.

14. Liuzzo, L., Bono, E., Sammartano, V. and Freni, G., Analysis of spatial and temporal rainfall trends in Sicily during the 1921-2012 period. Theor. Appl. Climatol., 2016, 126(1-2), 113-129.

15. Salmi, T., Määttä, A., Anttila, P., Ruoho-Airola, T. and Amnell, T., Detecting trends of annual values of atmospheric pollutants by the Mann-Kendall test and Sen's slope estimates - the Excel template application MAKESENS. In Publications on Air Quality No. 31, Finnish Meteorological Institute, Helsinki, Finland, 2002.

16. Theil, H., A rank invariant method of linear and polynomial regression analysis, Part 3. Netherlands, Akademie van Wettenschappen, Proceedings, 1950, 53, 1397-1412.

17. Sen, P. K., Estimates of the regression coefficient based on Kendall's tau. J. Am. Stat. Assoc., 1968, 63(324), 1379-1389.

18. Tabari, H., Talaee, P. H., Ezani, A. and Some'e, B. S., Shift changes and monotonic trends in autocorrelated temperature series over Iran. Theor. Appl. Climatol., 2011, 109(1-2), 95-108.

19. Dinpashoh, Y., Jhajharia, D., Fakheri-Fard, A., Singh, V. P. and Kahya, E., Trends in reference crop evapotranspiration over Iran. J. Hydrol., 2011, 399(3), 422-433.

20. Von Storch, H., Misuses of statistical analysis in climate research. In Analysis of Climate Variability: Applications of Statistical Techniques (eds Storch, H. V. and Navarra, A.), Springer, Berlin, Germany, 1995, pp. 11-26.

21. Tabari, H. and Talaee, P. H., Analysis of trends in temperature data in arid and semi-arid regions of Iran. Global Planet. Change, 2011, 79(1), 1-10. 
22. Rivard, C. and Vigneault, H., Trend detection in hydrological series: when series are negatively correlated. Hydrol. Process., 2009, 23(19), 2737-2743.

23. Yue, S., Pilon, P., Phinney, B. and Cavadias, G., The influence of autocorrelation on the ability to detect trend in hydrological series. Hydrol. Process., 2002, 16(9), 1807-1829.

24. Durbin, J. and Watson, G. S., Testing for serial correlation in least squares regression. I. Biometrika, 1950, 37(3/4), 409-428.

25. Durbin, J. and Watson, G. S., Testing for serial correlation in least squares regression. II. Biometrika, 1951, 38(1/2), 159-177.

26. Durbin, J. and Watson, G. S., Testing for serial correlation in least squares regression. III. Biometrika, 1971, 58(1), 1-19.

27. Naidu, C. V., Durgalakshmi, K., Krishna, K. M., Rao, S. R., Satyanarayana, G. C., Lakshminarayana, P. and Rao, L. M., Is summer monsoon rainfall decreasing over India in the global warming era? J. Geophys. Res., 2009, 114(D24), 1-16.

28. Malik, N., Bookhagen, B. and Mucha, P. J., Spatiotemporal patterns and trends of Indian monsoonal rainfall extremes. Geophys. Res. Lett., 2016, 43(4), 1710-1717.

29. Paul, S., Ghosh, S., Oglesby, R., Pathak, A., Chandrasekharan, A. and Ramsankaran, R. A. A. J., Weakening of Indian summer monsoon rainfall due to changes in land use land cover. Sci. Rep., 2016, 6, 32177; doi:10.1038/srep32177.

ACKNOWLEDGEMENTS. I thank Mr Kamakhya Bose (Office of Deputy Director of Agriculture (Administration), Maldah district, Government of West Bengal) for providing the necessary climatic data. I also thank Mr Martin Jakob (Institute of Cell Biology, University Bern, Switzerland) and Mr Jason Michael Whyte (University of Melbourne, Australia) for assistance.

Received 19 September 2018; revised accepted 25 November 2019

doi: $10.18520 / \mathrm{cs} / \mathrm{v} 119 / \mathrm{i} 6 / 1031-1038$

\section{Food availability rhythm affects reproduction in consecutive generations of ladybird, Propylea dissecta}

\author{
Arshi Siddiqui ${ }^{1,2}$, Omkar $^{1}$ and \\ Geetanjali Mishra ${ }^{1, *}$ \\ ${ }^{1}$ Ladybird Research Laboratory, Department of Zoology, \\ University of Lucknow, Lucknow 226 007, India \\ ${ }^{2}$ Department of Bioscience, Integral University, Dasauli Kursi Road, \\ Lucknow 226 026, India
}

Transgenerational effect on developmental attributes of insects has been studied extensively. The present study elucidates the role of diet on transgenerational developmental duration and reproductive attributes of

*For correspondence. (e-mail: geetanjalimishra@hotmail.com)

1038
Propylea dissecta (Mulsant). We have found a significant direct and transgenerational role of diet variations in feeding rhythms on the above attributes of $P$. dissecta. Dampened response was found in offspring fed on intermittent diet even when their parental generation was provided abundant food supply. Reduced reproductive attributes were found in the progeny of abundant diet parents reared on intermittent diet than the kin of the same abundant fed parents which were under other diet conditions.

Keywords: Feeding behaviour, ladybirds, pea aphid, stress, transgenerational effect.

THE environment affects reproduction as well as development of an individual directly and/or indirectly. Direct effect on development and reproduction of multiple taxa including insects are mediated through resource availability, resource quality, climate variations ${ }^{1}$, and many other environmental factors ${ }^{2}$. When environment affects the parents and influences the development and reproduction of their progeny, indirect environmental effects are seen. Often, this is known to occur through parental exposure and experience $\mathrm{e}^{3,4}$. The nutritional environment of the parental generation can probably influence the developmental and reproductive potential of the next generation through food-based maternal effects ${ }^{5}$. Diet manipulations are possibly associated with increased longevity as well as stress tolerance, ${ }^{6,7}$ in the offspring of starved diet parents; for example, as in ladybird Anegleis cardoni (Weise) $)^{5}$.

Reynolds et $a l .{ }^{8}$ reported that most insects feed in bouts and have varying inter-feed gap lengths. Also, the feeding period length of many insects is strongly correlated to the preceding inter-feed gap duration'. Food deprivation is compensated by controlling the total percentage of feeding time by adjusting feed bout length or inter-feed gap length.

Studies have shown volumetric feedback response to regulate meal length variability through gut stretch receptors $^{10,11}$. There are other mechanisms between feeding extremes that indicate patterns and trends extending from minutes to hours. Previous studies also indicate that rhythmic cycles are common in biological environments, ranging from very fast biochemical alternations of seconds or milliseconds inside cells to circadian rhythms of individual organisms ${ }^{12}$. Thus, we hypothesized the following in the present study in two consecutive generations: (1) whether responses were dependent on the frequency of food deprivation, and (2) whether the effect of food deprivation on developmental plasticity is transferred to the offspring through parental effect. Thus, the main aim in the transgenerational assessments was to evaluate whether progeny from starved parents were inclined to cope with the lack of food by parental perceptions. 